\title{
Využití pokročilých metod dokumentace místa dopravní nehody policií ČR
}

\author{
Use of Advanced Documentation Methods of Traffic Accidents of Police Czech Republic
}

\author{
Ivo Stáňa ${ }^{\mathrm{a}^{*}}$, Jindřich Rybka ${ }^{\mathrm{a}}$, Milan Novák ${ }^{\mathrm{b}}$, Kateřina Bucsuházy ${ }^{\mathrm{c}}$
}

${ }^{a}$ Krajské Ředitelství Policie Jihomoravského kraje

${ }^{b}$ Krajské Ředitelstvi Policie Ústeckého kraje

${ }^{c}$ Vysoké učení technické v Brně, Ústav soudního inženýrství

\begin{abstract}
Abstrakt
Bezchybná, přesná dokumentace místa dopravní nehody je jedním z hlavních předpokladů a vstupních údajů pro technicky přijatelnou analýzu nehodového děje. Základními prostředky, které poskytují ucelenou informaci o místě dopravní nehody, jsou v České republice protokol o nehodě v silničním provozu, protokol o ohledání místa dopravní nehody, fotografická a topografická dokumentace, tedy podklady vyhotovené policií. Cílem tohoto př́spěvku je představit zavádění vybraných pokročilých metod dokumentace místa dopravní nehody do běžné policejní praxe. Př́spěvek byl publikován na Mezinárodní vědecké konferenci soudního inženýrství ExFoS 2019.
\end{abstract}

Klíčová slova: dopravní nehoda, dokumentace, totální geodetická stanice, jednosnímková fotogrammetrie, policie.

\section{1. ÚVOD}

Pro využití v soudně - inženýrské praxi při analýze silničních nehod je dokumentace místa dopravní nehody jedním z nejdůležitějších podkladů. Na jejím základě je dopravní nehoda analyzována, je tedy rozhodující pro zpětné určení průběhu nehodového děje a případně i následné určení míry zavinění účastníků dopravní nehody v rámci správního či trestního řízení. Při ohledání místa dopravní nehody musí být kladen důraz nejen na přesnost a pečlivost prováděných úkonů, ale rovněž na efektivitu a minimalizaci časové náročnosti užitých metod ohledání a dokumentace. Odbor služby dopravní policie Krajského ředitelství policie Jihomoravského kraje v úzké spolupráci s Ústavem soudního inženýrství VUT v Brně, se právě problematikou ověřování vybraných pokročilých metod dokumentace místa dopravní nehody a jejich zavádění do běžné policejní praxe zabývají.

\begin{abstract}
Documentation of a traffic accident site is one of the main assumptions and inputs for the subsequentional accident analysis. The basic, providing comprehensive information on the location of a traffic accident, are traffic accident protocol, accident site survey protocol, photographic and topographic documentation made by the police. The aim of this paper is to introduce the usage of selected advanced methods of documentation of a traffic accident site into common police practice. The paper was published at the International Scientific Conference of Forensic Engineering ExFoS 2019.
\end{abstract}

Keywords: traffic accident, documentation, geodetic total station, photographic rectification, police.

Skutečnost, že se jedná o aktuální problematiku nejen v podmínkách České republiky, potvrzují současné výzkumy prováděné v zahraničí. Pro dokumentaci dopravních nehod jsou v posledních letech stále častěji využívány laserové 3D scannery např. [1], [2]. Nevýhodou této metody dokumentace je náročnost následného zpracování a uchování rozsáhlých souborů získaných dat. Aktuální výzkumy často popisují výhody využití vícesnímkové fotogrammetrie [3], [4], [5]. Jedná se o techniku, která umožňuje měření objektů $z$ fotografií. Velkou výhodou této metody je zrychlení práce na místě dopravní nehody. Doba potřebná pro následné zpracování je ovšem delší než při využití konvenčních metod. Hlavní nevýhodou je obtížnost při dokumentaci míst s výrazným výškovým profilem a především velmi rozlehlých míst dopravních nehod [2]. 


\section{VYUŽÍTÍ MODERNÍCH METOD DOKUMENTACE MÍSTA DN}

\subsection{Využívání moderních metod dokumentace v zahraničí}

Moderní metody a prostředky dokumentace míst dopravních nehod uvedené $\mathrm{v}$ předchozí kapitole již jsou v praxi využívány některými policejními složkami v zahraničí. Využívání jednotlivých metod dokumentace se často liší nejen v závislosti na závažnosti nehody, ale rovněž mezi jednotlivými policejními jednotkami nebo státy.

Jeden z nejmodernějších v současné době používaných prostředků dokumentace místa dopravní nehody - laserový 3D skener je využíván policejními jednotkami nejen v USA, ale rovněž v Evropě (Velká Británie, Švýcarsko) a MCIS (Major Crash Investigation Section) v Austrálii. Často využívanou metodou dokumentace místa dopravní nehody je rovněž geodetické zaměření. [6], [3].

$\mathrm{V}$ řadě př́ípadů je také využívána kombinace jednotlivých metod. Např́klad National police Chiefs Council v Anglii a jeho specializované vyšetřovací týmy využívají nejen geodetické totální stanice, ale také snímkování s využitím dronů [7]. Oproti tomu např́klad Washington State Police pak využívá kombinace fotogrammetrie spolu se zaměřením pomocí totální stanice [3] Přesto stále velké množství policejních oddělení v zahraničí využívá

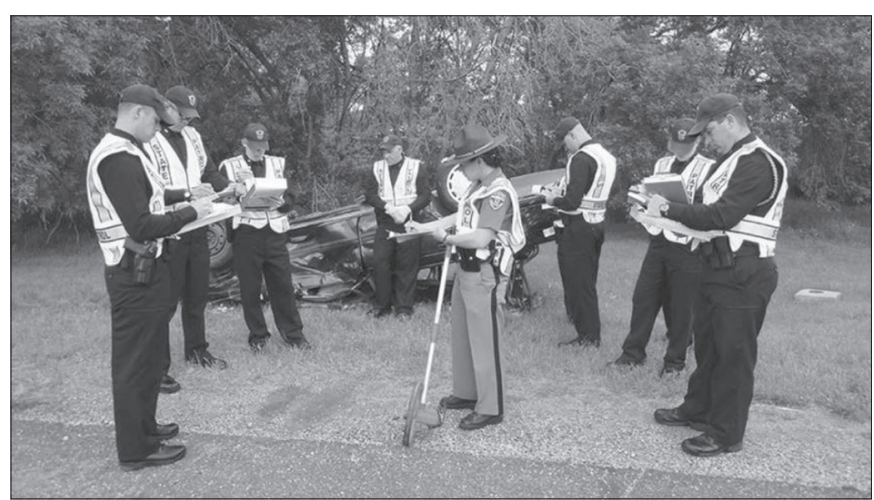

Obr. 1 Výcvik policistů.

Fig. 1 Training of police officers. pro dokumentaci místa dopravní nehody pravoúhlé zaměření pomocí měřického kolečka a pásma (obr. 1).

\subsection{Současný stav u Policie ČR}

Z vnějšího pohledu by se mohlo zdát, že v postupech při ohledání místa dopravní nehody a jeho dokumentaci u Policie České republiky došlo $\mathrm{v}$ posledních letech $\mathrm{k}$ velmi málo změnám. Rozšíření 3D skenerů do rutinní policejní práce v České republice ve srovnatelné míře jako v zahraničí brání zejména vysoké pořizovací náklady nejen těchto zařízení, ale i počítačového vybavení a speciálních programů pro následné zpracování získaných dat.

Plošnému používání dronů při dokumentaci dopravních nehod v současné době brání především stávající právní úprava, která neumožňuje (ani pro státní orgány) provoz těchto bezpilotních prostředků nad zastavěnými oblastmi, nad osobami, nad pozemními komunikacemi, kde není vyloučen provoz, v ochranných pásmech letišt’ či elektrického vedení apod. Proto jsou bezpilotní prostředky provozovány pouze některými vybranými útvary Policie ČR, kterými je Letecká služba a Služba cizinecké a pohraniční policie. Možnost běžného využíání dronů pro dokumentaci místa dopravní nehody je tak spíše teoretická, přestože není vyloučena.

Jako nejvhodnější varianta inovace při topografické dokumentaci místa dopravní nehody v podmínkách Policie ČR se v současné době jeví využití geodetických totálních stanic, kterými jsou vybavena všechna nehodová výjezdová vozidla. Efektivita jejich využití a vliv na zpřesnění policejní práce na místě dopravní nehody i při následném zpracování byly rozsáhle testovány $\mathrm{v}$ rámci spolupráce Krajského ředitelství policie Jihomoravského kraje a Ústavu soudního inženýrství VUT v Brně [8], [9], [10], který má s využitím tohoto způsobu dokumentace dlouholeté zkušenosti. Pokročilé metody dokumentace byly testovány př́imo v praxi u několika desítek závažných dopravních nehod s následky na životě a zdraví osob. Na základě provedeného testování bylo jednoznačně prokázáno zásadní zpřesnění samotné dokumentace a výrazná časová úspora zvláště při následném zpracování naměřených dat do plánku a protokolu o ohledání místa dopravní nehody.

voprava

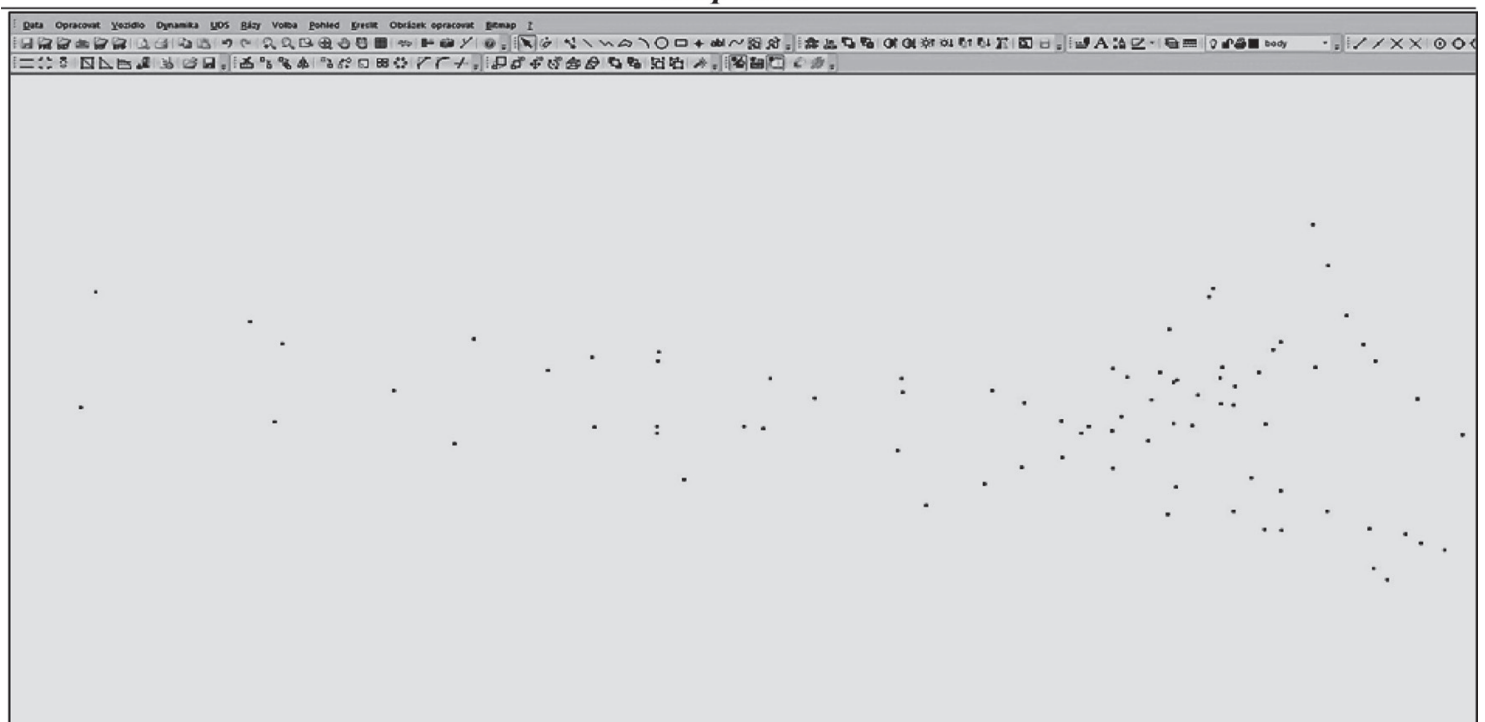

Obr. 2 Výsledný obraz zaměřených bodi̊ po exportu do PC-Draw.

Fig. 2 The resulting image of points after export to PC-Draw. 


\section{POSTUPNÉ ZAVÁDĚNÍ NOVÝCH METOD DOKUMENTACE MÍSTA DOPRAVNÍ NEHODY DO POLICEJNÍ PRAXE}

\subsection{Využití totální geodetické stanice k topografické dokumentaci místa dopravní nehody}

Přestože služba dopravní Policie ČR byla již v průběhu roku 2016 vybavena totálními geodetickými stanicemi GPI 122L a současně využívá ke kreslení plánků dopravních nehod program PCDraw, který vychází z PC-Crash verze 10, jejich plné využívání se neobešlo bez problémů. Bylo nutné odstranit nedostatky způsobené „,nekompatibilitou“ měřicího zařízení a používaného kreslícího programu. Dodavatel totální geodetické stanice sice poskytl program pro konverzi naměřených dat do formátu *dxf, ale výsledný obrázek nebylo možné importovat do programu PCDraw s číselným označením zaměřených bodů. Řešení spočívající v ručním odmazání označení zaměřených bodů ve zdrojovém souboru bylo zdlouhavé, uživatelsky nepřivětivé a výsledný obraz v kreslícím programu byl značně nepřehledný (obr. 2).

\subsection{Nová metodika zaměřování místa dopravní nehody}

Obdobnou formu spolupráce jako Krajské ředitelství policie Jihomoravského kraje s Ústavem soudního inženýrství VUT v Brně má i Krajské ředitelství policie Ústeckého kraje s Ústavem soudního znalectví v dopravě Fakulty dopravní ČVUT v Praze. Výstupem jejich společné práce je metodika zaměřování totální geodetickou stanicí a program pro převod naměřených dat do formátu *dxf.. Hlavním př́nosem tohoto programu je odstranění problémů s kompatibilitou výstupních dat z totální geodetické stanice. Program zajišt'uje komfortní přenos dat do programu PC-Draw včetně popisu zaměřených bodů a vytvoření legendy plánku (obr. 3).

Mimo to nově vyvinutý program umožňuje částečně automatizovanou tvorbu popisu stop v protokolu o ohledání místa dopravní nehody $\mathrm{v}$ přehledném a srozumitelném technickém formátu, kdy jednotlivé body (stopy, vozidla, tvar komunikace apod.) jsou v prostoru zaměřeny v kartézském souřadném systému ve třech osách $x, y, z$ a současně je zaměřena př́má vzdálenost bodů od výchozího bodu měření (VBM). Podstatným rozdílem oproti dlouhodobě zaužívaným metodám topografické dokumentace je, že jako VBM již není vzat pevný relativně neměnný bod v terénu, od kterého probíhá zaměřování. Nově je VBM místo ustanovení totální geodetické stanice, které je $\mathrm{v}$ prostoru orientováno zaměřením proti třem pevným pomocným bodům měření, kterými mohou být rohy budov, sloupy veřejného osvětlení či jiné relativně stálé a neměnné objekty. Zaměření pomocných bodů umožňuje $\mathrm{v}$ prrípadě potřeby při případné rekonstrukci na místě dopravní nehody pozdější zpětnou identifikaci VBM a přezkoumatelnost naměřených vzdáleností (obr. 4).

\section{VYUŽÍVÁNÍ MODERNÍCH METOD DOKUMENTACE POLICIÍ V JIHOMORAVSKÉM KRAJI}

Názorným prríkladem praktického využití zaměření místa dopravní nehody pomocí totální geodetické stanice je závažná dopravní nehoda, při které došlo ke dvěma smrtelným a dvěma těžkým zraněním. Jednalo se o čelní střet dvou osobních vozidel, po kterém jedno z vozidel zůstalo v konečné poloze na poli ve vzdálenosti cca $30 \mathrm{~m}$ od pozemní komunikace a cca $8 \mathrm{~m}$ pod úrovní náspu dálničního přivaděče. Na místě dopravní nehody se nacházelo velké množství tvarově poměrně složitých blokovacích a smykových stop pneumatik obou vozidel. Dokumentace místa události byla navíc prováděna $v$ noční době, proto byla část stop pouze označena čísly, zvýrazněna pomocí značkovacího spreje a zadokumentována fotograficky. Geodetické zaměření těchto stop totální stanicí bylo provedeno následující den $\mathrm{v}$ rámci dodatečného ohledání místa nehody. Při zpracování plánku byly pro zpřesnění stopy postřetového pohybu jednoho ze zúčastněných vozidel vloženy z jejich rektifikované fotografie (obr. 5).

Příklad popisu stop v novém formátu protokolu o ohledání místa dopravní nehody popsaný v kapitole 3.2 tohoto článku je na obr. 6 .

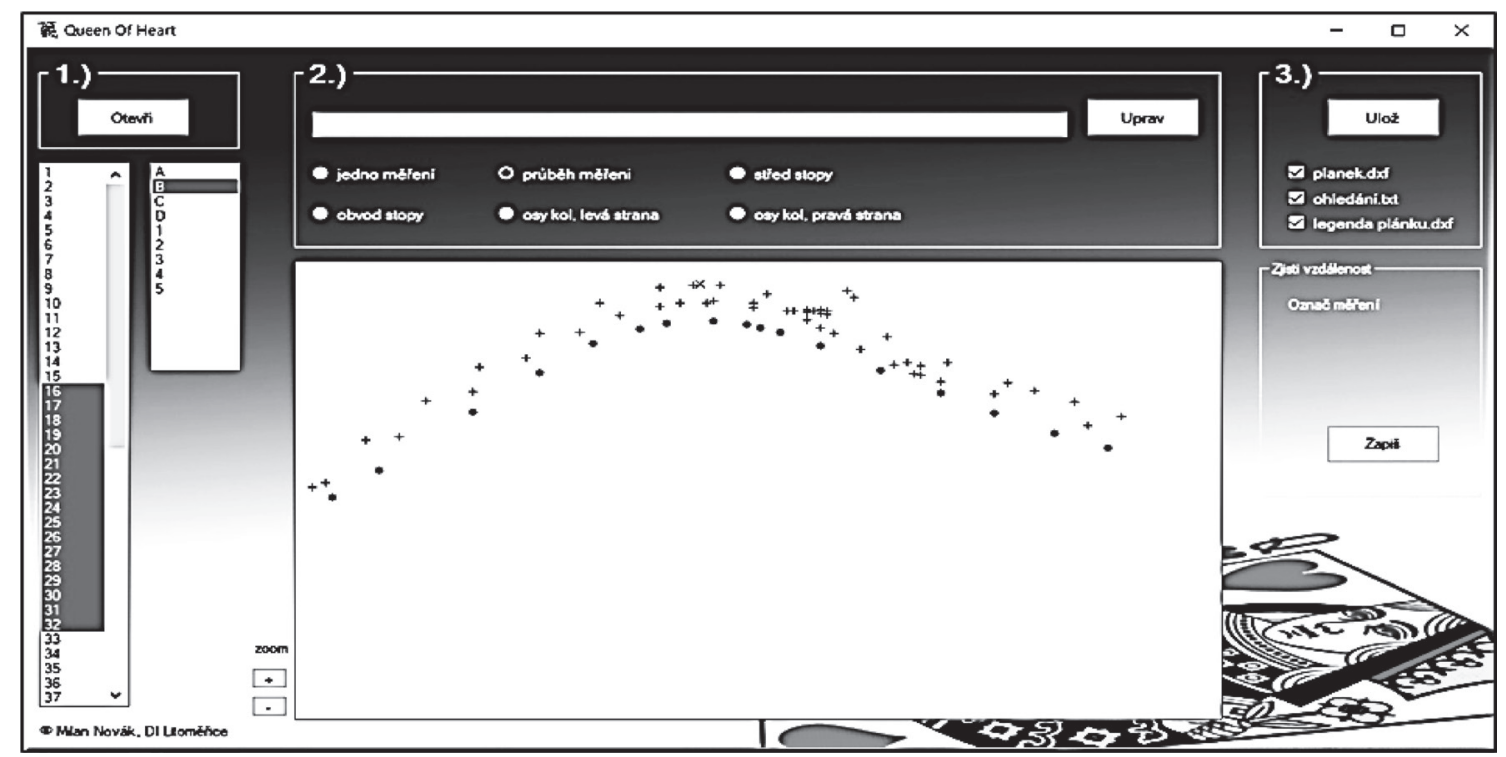

Obr. 3 Program pro prenos dat do PC-Draw.

Fig. 3 Program for data transfer to PC-Draw. 


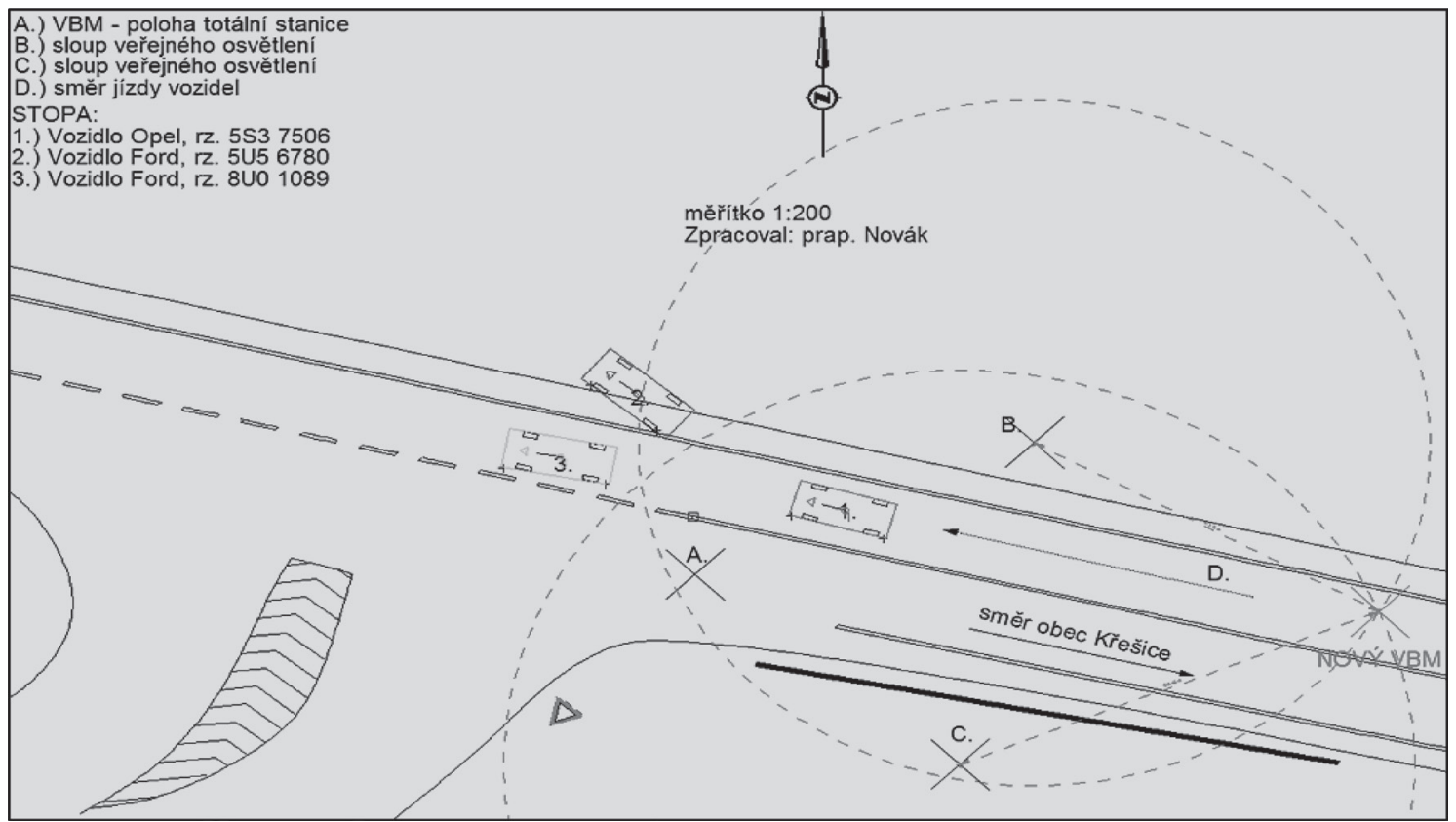

Obr. 4 Rekonstrukce VBM a mista dopravni nehody.

Fig. 4 Reconstruction of starting point of measurement and accident site.

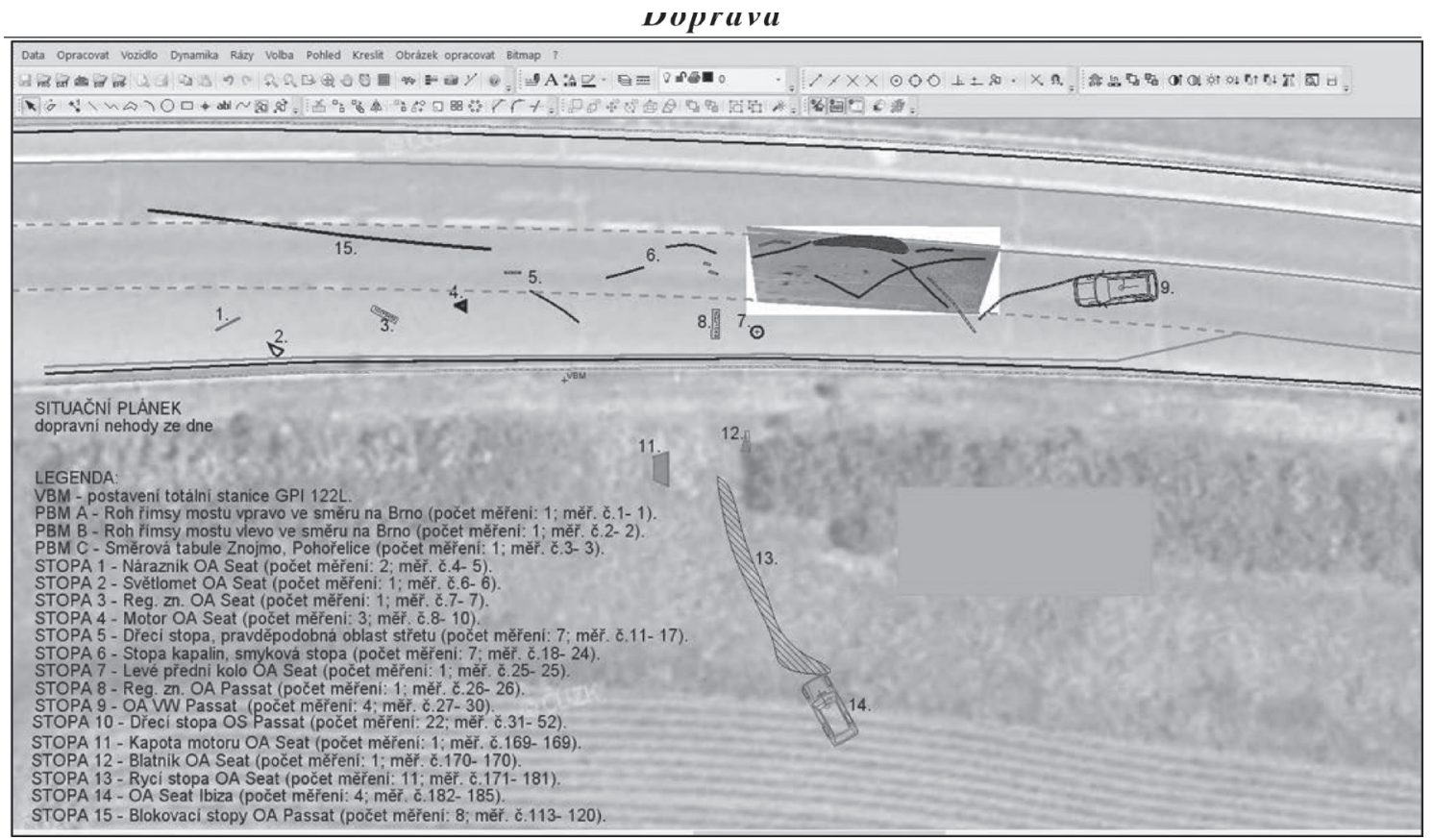

Obr. 5 Plánek místa dopravni nehody.

Fig. 5 Sketch of the traffic accident site.

\section{ZÁVĚR}

Zkušenosti získané v průběhu ověřování dokládají výrazné zpřesnění a především zefektivnění ohledání místa dopravní nehody provedené s využitím kombinace zaměření místa pomocí geodetické totální stanice a fotodokumentace stop s vybranými body pro následnou rektifikaci. V současné době probíhá dalši vývoj programového prostředí pro export dat z totální stanice. Dalším krokem bude rovněž tvorba inovované metodiky ohledání místa dopravní nehody. Nová metodika bude reflektovat vývoj v této oblasti a rovněž zpětnou vazbu zejména od znalců z oboru dopravy, kteří budou podklady od PČR využívat při následné analýze nehodového děje. Cílem metodiky bude přímá aplikace získaných zkušeností ve využívání moderních prostředků dokumentace do běžné policejní praxe při dokumentaci závažných dopravních nehod.

U dopravních nehod, kde se v rozlehlém místě nachází značné množství stop, se konvenční způsob zaměření pomocí měřického kolečka jeví jako nepřesný a dnes již překonaný. Z hlediska přesnosti může dojít při použití měřického kolečka či pásma 
K zaměření stop a vymęření místa dopravní nehody je využita totální stanice GPI -122L. Stopy jsou zaměrovány v prostoru, $k d y$ bodu VBM ( v́x́chozi bod měrení) je priirazena hodnota $(x=0, y=0, z=0)$. Bod VBM je vyměřen za pomoci bodủ PBM1 (pomocný bod měření), PBM2 a PBM3. Osa $x$ je zvolena Kolmo k levému okraji pozemní komunikace ve směru jizdy na Brno. Osa y přiléhá kolmo k ose x vodorovně. Osa $z$ přiléhá kolmo $k$ ose $x$ svisle. Souřadnice bodu jsou zapisovány v pořadi x X

PBM A - Roh římsy mostu vpravo ve směru na Brno. Pomocný bod měření je zaměřen v jednom bodě. Zaměřený bod:" Měření č. 1. PBM A. Poloha bodu zaměřena na souřadnicích $(65,76 ;-2,71 ; 1,73)$, ve vzdálenosti 65,85 metrủ od VBM. PBM B - Roh římsy mostu vlevo ve směru na Brno. Pomocný bod měření je zaměřen v jednom bodě. Zaměřený bod:" Měření č. 2. PBM B. Poloha bodu zaměřena na souřadnicích $(60,41 ; 9,58 ; 1,97)$, ve vzdálenosti 61,21 metrů od VBM. PBM C - Smĕrová tabule Znojmo, Pohořelice. Pomocný bod měřeni je zamĕřen v jednom bodě. Zaměřený bod:" Měření č. 3. PBM C. Poloha bodu zaměřena na souřadnicích $(-11,67 ; 16,07 ;-0,14)$, ve vzdálenosti 19,86 metrů od VBM.

STOPA 1 - Nárazník OA Seat. Stopa je označena čislem 1 Vyměřován je prủběh stopy, kdy jednotlivá měření jşou zaměřena $v$ bodech zvýraznèné sprejem. Zaměřené body:

Měření č. 4. Poloha bodu zaměřena na sour̆adnicích $(-19,98 ; 2,85 ;-0,52)$, ve vzdálenosti 20,19 metrủ od VBM.

Měření č. 5 . Poloha bodu zaměřena na souřadnicích $(-18,59 ; 3,58 ;-0,46)$, ve vzdálenosti 18,93 metrů od VBM.

STOPA 2 - Světlomet OA Seat. Stopa je zaměřena v jednom bodě. Tento bod je označen popisem stopy a je zvýrazněn sprejem. Zaměřený bod:

Měření č. 6 . Poloha bodu zaměřena na sour̆adnicích $(-16,11 ; 1,72 ;-0,44)$, ve vzdálenosti 16,2 metrů od VBM.

STOPA 3 - Reg. zn. OA Seat. Stopa je zaměřena $v$ jednom bodě. Tento bod je označen popisem stopy a je zvýrazněn sprejem. Zaměřený bod:

Měření č. 7. Poloha bodu zaměřena na souřadnicích $(-10,35 ; 3,96 ;-0,18)$, ve vzdálenosti 11,08 metrů od vBM.

STOPA 4 - Motor OA Seat. Stopa je označena číslem 4 Vyměřován je obvod stopy, kdy jednotlivá měrení jsou zamęřena $v$ bodech zvýrazněné sprejem. Zaměřené body:

Měření č. 8. Poloha bodu zaměřena na souřadnicích $(-6,34 ; 4,29 ;-0,05)$, ve vzdálenosti 7,66 metrů od VBM.

Měření č. 9. Poloha bodu zaměřena na souřadnicích $(-5,65 ; 4,58 ;-0,01)$, ve vzdálenosti 7,28 metrů od VBM.

Měření č. 10. Poloha bodu zaměřena na souřadnicích $(-5,65 ; 3,92 ;-0,04)$, ve vzdálenosti 6,89 metrů od VBM.

Obr. 6 Nový formát popisu stop v protokolu o ohledání místa DN.

Fig. 6 The new track description format in the accident site survey protocol.

$\mathrm{k}$ odchylce $\mathrm{v}$ řádu jednotek \%, což ovšem u rozlehlejších míst dopravních nehod může znamenat odchylku několika metrů. Při použití totální geodetické stanice je odchylka maximálně v řádu jednotek centimetrů $\mathrm{v}$ celém měřeném úseku (stovky metrů). Cílem tohoto článku je představení zavedení pokročilých metod dokumentace dopravní nehody do běžné práce dopravních policistů Policie ČR. Přestože publikované výsledky [8], [9], [10] dokládají značné časové úspory a rovněž zpřesnění výsledků měření, toto zdánlivě jednoduché a dostatečně vypovídající srovnání může být částečně zkreslené, nebot' nezohledňuje vliv lidského faktoru na přesnost provedeného měření, který může být značný. $\mathrm{S}$ tím přímo souvisí i nutnost průběžného školení dopravních policistů a rozvoj jejich dovedností v oblasti dokumentace místa dopravní nehody s využitím moderních prostředků a metod, nebot' nedostatečná praxe má vliv nejen na přesnost výsledku, ale i na dobu činnosti na místě dopravní nehody.

\section{LITERATURA}

[1] PAGOUNIS, V., et al. 3D laser scanning for road safety and accident reconstruction. Proceedings of the XXIII th international FIG congress, 2006, p. 8-13.

[2] WALTON, J. R., BARRETT, M. L. AGENT, K. R. Evaluation of Methods to Limit the Time Taken to Investigate Crash Sites. 2005.

[3] ARNOLD Jr., E. D. Use of Photogrammetry as a Tool for Accident Investigation and Reconstruction. A Review of the Literature and State of the Practice, 2007.

[4] COONER, S. A., BALKE, K. N. Use of photogrammetry for investigation of traffic incident scenes. 2000.
[5] FRASER, C. CRONK, S. HANLEY, H. Close-range photogrammetry in traffic incident management. Proceedings of XXI ISPRS congress commission V, WG V, Citeseer. 2008, p. $125-128$.

[6] ROPERO - MILER, J. a kol. Landscape study on 3D crime scene scanning devices. National Institute of Justice. 2016.

[7] BARRY, S. Police collision investigation procedures. Parliamentary advisory council for transport safety Conference: Collision investigation - how can we learn more?

[8] STÁŇA, I., TOKAŘ, S., BILÍK, M. Možnosti zaměření místa dopravní nehody s využitím ortofotosnímků. Sborník anotací konference Junior Forensic Science, Ústav soudního inženýrství Vysokého učení technického v Brně, 2016.

ISBN 978-80-214-5336-4.

[9] TOKǍ̌, S.; STÁŇA, I.; BILÍK, M. Porovnání možností zaměreni mista dopravni nehody. In Expert Forensic Science 2016. Brno. Vysoké učení technické v Brně. Vysoké učení technické, Ústav soudního inženýrství, ISBN: 978-80-214-5321-0.

[10] STÁŇA, I., TOKǍ̌, S., BUCSUHÁZY, K., BILÍK, M. Comparison of utilization of conventional and advanced methods for traffic accidents scene documentation in the Czech Republic. Proceedings of the $10^{\text {th }}$ International Scientific Conference Transbaltica 2017: Transportation Science and Technology, 2017.

[11] STÁŇA, I., RYBKA, J., NOVÁK, M., BUCSUHÁZY, K. Využití pokročilých metod dokumentace místa dopravní nehody Policií ČR. Sbornik anotaci konference Expert Forensic Science, Ústav soudního inženýrství Vysokého učení technického v Brně, 2019. ISBN 978-80-214-5708-9.

\section{Správná citace:}

STÁŇA, I., RYBKA, J., NOVÁK, M., BUCSUHÁZY, K. Využití pokročilých metod dokumentace místa dopravní nehody policií ČR. Soudní inženýrství, 2019, 30(2), 3-7. DOI: http://dx.doi.org./10.13164/SI.2019.2.3. ISSN 1211-443X. 